\title{
Front Matter: Volume 11409
}

, "Front Matter: Volume 11409," Proc. SPIE 11409, Thermosense: Thermal Infrared Applications XLII, 1140901 (17 June 2020); doi: 10.1117/12.2572666

SPIE. Event: SPIE Defense + Commercial Sensing, 2020, Online Only 


\title{
PROCEEDINGS OF SPIE
}

\section{Thermosense: Thermal Infrared Applications XLII}

\author{
Beate Oswald-Tranta \\ Joseph N. Zalameda \\ Editors
}

27 April - 8 May 2020

Online Only, United States

Sponsored and Published by

SPIE 
The papers in this volume were part of the technical conference cited on the cover and title page. Papers were selected and subject to review by the editors and conference program committee. Some conference presentations may not be available for publication. Additional papers and presentation recordings may be available online in the SPIE Digital Library at SPIEDigitalLibrary.org.

The papers reflect the work and thoughts of the authors and are published herein as submitted. The publisher is not responsible for the validity of the information or for any outcomes resulting from reliance thereon.

Please use the following format to cite material from these proceedings:

Author(s), "Title of Paper," in Thermosense: Thermal Infrared Applications XLII, edited by Beate Oswald-Tranta, Joseph N. Zalameda, Proceedings of SPIE Vol. 11409 (SPIE, Bellingham, WA, 2020) Seven-digit Article CID Number.

ISSN: 0277-786X

ISSN: 1996-756X (electronic)

ISBN: 9781510635951

ISBN: 9781510635968 (electronic)

Published by

SPIE

P.O. Box 10, Bellingham, Washington 98227-0010 USA

Telephone +1 3606763290 (Pacific Time) · Fax +1 3606471445

SPIE.org

Copyright (c) 2020, Society of Photo-Optical Instrumentation Engineers.

Copying of material in this book for internal or personal use, or for the internal or personal use of specific clients, beyond the fair use provisions granted by the U.S. Copyright Law is authorized by SPIE subject to payment of copying fees. The Transactional Reporting Service base fee for this volume is $\$ 21.00$ per article (or portion thereof), which should be paid directly to the Copyright Clearance Center (CCC), 222 Rosewood Drive, Danvers, MA 01923. Payment may also be made electronically through CCC Online at copyright.com. Other copying for republication, resale, advertising or promotion, or any form of systematic or multiple reproduction of any material in this book is prohibited except with permission in writing from the publisher. The CCC fee code is $0277-$ $786 \mathrm{X} / 20 / \$ 21.00$.

Printed in the United States of America by Curran Associates, Inc., under license from SPIE.

Publication of record for individual papers is online in the SPIE Digital Library.

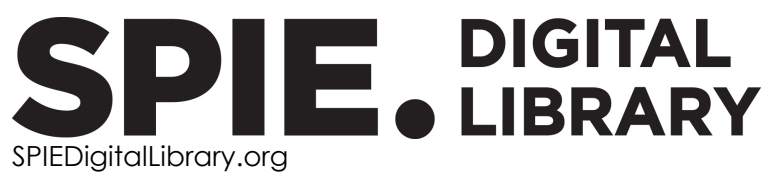

Paper Numbering: Proceedings of SPIE follow an e-First publication model. A unique citation identifier (CID) number is assigned to each article at the time of publication. Utilization of CIDs allows articles to be fully citable as soon as they are published online, and connects the same identifier to all online and print versions of the publication. SPIE uses a seven-digit CID article numbering system structured as follows:

- The first five digits correspond to the SPIE volume number.

- The last two digits indicate publication order within the volume using a Base 36 numbering system employing both numerals and letters. These two-number sets start with $00,01,02,03,04$, 05, 06, 07, 08, 09, OA, OB ... 0Z, followed by 10-1Z, 20-2Z, etc. The CID Number appears on each page of the manuscript. 


\section{Contents}

vii Tribute to Paul Zayicek

ix Tribute to Ralph Dinwiddie

\section{BIOLOGICAL APPLICATIONS}

1140902 Excitation profile extraction in thermal transient imaging using equivalent wave field transform and principal components thermography [1 1409-1]

$1140903 \quad$ Identification of bone cancer in canine thermograms [1 1409-2]

$1140904 \quad$ Analytic models to predict root structure depth [1 1409-3]

$1140905 \quad$ Soilytics, replacing chemistry with physics: hyperspectral infrared imaging replaces testing by loss on ignition organic matter method [11409-4]

$1140906 \quad$ Automated detection, tracking, and counting of gray whales [11409-43]

1140907 Infrared thermography-based human respiration monitoring [11409-5]

1140908 Infrared thermography-based smart irrigation scheduling for horticulture plants [11409-6]

INFRARED NDT

11409 OB Fast detection of defects in glass-soldered fuel cell assemblies by active infrared thermography [11409-10]

11409 OC Comparison of different inspection techniques for fatigue cracks [11409-11]

11409 OD Induction thermography-based inspection of EBW and TIG welded Inconel 718 components: steps towards industrialization [1 1409-12]

\section{IR NDT FOR COMPOSITES STRUCTURES}

11409 OF Study of damage of t-joint components by using different non-destructive techniques [1 1409-14]

11409 OG Assessment of the quality of adhesive bond in t-joints coupons by using thermoelastic stress analysis [11409-15] 
$11409 \mathrm{OH} \quad$ Online thermography inspection for automated tape layup [1 1409-16]

11409 Ol Non-destructive thermography-based system for damage localisation and characterisation during induction welding of thermoplastic composites [11409-19]

11409 0J Pulse thermography applications in aerospace composites manufacturing processes [1 1409-20]

\section{D THERMAL RECONSTRUCTION AND INVERSION TECHNIQUE}

11409 OK Quadrupole simulations of three-dimensional structures (Invited Paper) [11409-21]

$11409 \mathrm{OL} \quad 3 \mathrm{D}$ reconstruction of thermal volumetric sources from surface temperature fields measured by infrared thermography (Invited Paper) [11409-22]

11409 ON How to characterize buried heat sources from surface temperature data: a regularized least square minimization approach (Invited Paper) [11409-24]

11409 OP Photothermal porosity estimation in carbon fiber reinforced plastics based on the virtual wave concept [1 1409-27]

\section{DATA ANALYSIS FOR NDT I}

$114090 Q \quad$ Evaluation of clustering algorithms for the analysis of thermal NDT inspections [1 1409-28]

11409 OR Acquisition and processing of passive thermography fatigue test data [1 1409-29]

11409 OS Pulse compression favorable thermal wave imaging methods for testing and evaluation of carbon fibre reinforced polymer [1 1409-30]

\section{DATA ANALYSIS FOR NDT II}

11409 OT Automatic defect detection in infrared thermography by deep learning algorithm [11409-31]

11409 OU Reflectivity detection and reduction of thermographic images using image stitching technique and its applications on remote inspection [1 1409-32]

11409 OV Intelligent infrared thermography inspection of subsurface defects [11409-33] 
INDUSTRIAL APPLICATIONS

$114090 Z$ Quantitative radiation thermometry using commercially available high-speed video cameras [1 1409-17]

$1140910 \quad$ Monitoring the laser cutting process by IR thermography [11409-39]

1140912 Reimagining infrared industry with artificial intelligence and IoT/IIOT [1 1409-42] 
Proc. of SPIE Vol. 11409 1140901-6 Downloaded From: https://www.spiedigitallibrary.org/conference-proceedings-of-spie on 26 Apr 2023
Terms of Use: https://www.spiedigitallibrary.org/terms-of-use 


\section{Tribute to Paul Zayicek}

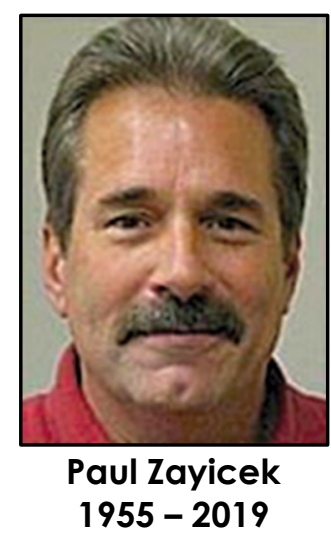

Paul Zayicek was born in Amsterdam, New York, north of Schenectady, on 5 November 1955, and grew up in nearby Johnstown, New York; he graduated from Johnstown High School in 1973. He attended SUNY Morrisville (west of Schenectady) (United States). He later earned his BS in Business Management from the University of Phoenix (United States).

Paul worked for General Electric in New York (United States) and 35 years ago, he moved to the Charlotte, North Carolina (United States) area to work at the Electric Power Research Institute (EPRI) in the Nuclear Nondestructive Evaluation (NDE) Center (United States). At EPRI he was a Project Manager supporting the Electric Power industry. Paul started the Infrared Thermography Users Group (IRUG) and managed it for more than 10 years. He was also responsible for Infrared Thermography (IRT) research in the Nuclear Division both in the Power Plants and in power Transmission and Distribution (T\&D). He provided input to the training materials still used at EPRI.

Paul was also involved in the ultrasonic inspection (UT) of turbine rotors, blade/buckets, and shrunk-on steam turbine disks.

He was certified in the NDT methods of Infrared Testing (IR), Ultrasonic Testing (UT) and Magnetic Particle Testing (MT).

Paul was a member of American Society of Nondestructive Testing (ASNT) since 1979, and in 2008, he was honored as a Fellow by that organization.

Paul was author and co-author of several books and scientific articles related to the use and application of IR Technology such as: Evaluation of IR technology applied to cooling tower performance, Practical Applications of Infrared Thermal Sensing and Imaging Equipment.

He began his participation in the Thermosense (SPIE) conference in the 1990's. In 1995 he presented his first paper, co-written with Herb Kaplan, entitled: "An Application of Differential Infrared Thermography in Power Generation Facilities". 
He served as the chairman of the Predictive Maintenance session from 1997 until 2000, and he was a member of the Thermosense Steering Committee.

After retiring from EPRI, he spent a short time with Westinghouse (Siemens). Then in 2011, he continued his career as a Product Manager (Turbine-Generators Senior Consultant), with the consulting firm Structural Integrity (SI) at the Charlotte Office in Huntersville, North Carolina. He held this position until he passed away.

The Thermosense community remembers Paul for the many contributions he made to IR technology.

Paul passed away far too soon on 6 September 2019 in Gastonia, North Carolina (United States).

Paul is survived by his wife and her sons, his daughter, his son, and their mother, several grandchildren, and his brother. Paul had a wide range of interests, including gardening, beekeeping, and the restoration of antique automobiles. He was dedicated to his family and his faith. Paul was one of those unique people that never seemed to get upset; he just rolled smoothly through difficult problems, and always flashed a genuine smile.

\section{Individual Tributes to Paul}

Paul, along with Doug Burleigh, Jane Spicer, Xavier Maldague, Takahide Sakagami, myself and others were part of the "younger" generation coming into Thermosense in the late 80's/early 1990's. Thermosense was a much larger conference at the time, and we were all part of a tectonic shift from preventative maintenance toward NDT. Paul was a strong supporter, and through his position at EPRI, was able to help promote the technology and move it toward the mainstream in its early days. I worked with him on a few projects and I think we published some work together. He was smart, straight-forward and funny... an unbeatable combination in my book.

Steve Shepard

Paul was quite supportive of Thermosense and it has been always nice to talk to him.

Xavier Maldague

I met him a couple of times at Thermosense and we always had pleasant discussions. It is always sad when people who make up "our" community gradually pass away.

Vlad (Vladimir Vavilov) 


\section{Tribute to Ralph Dinwiddie}

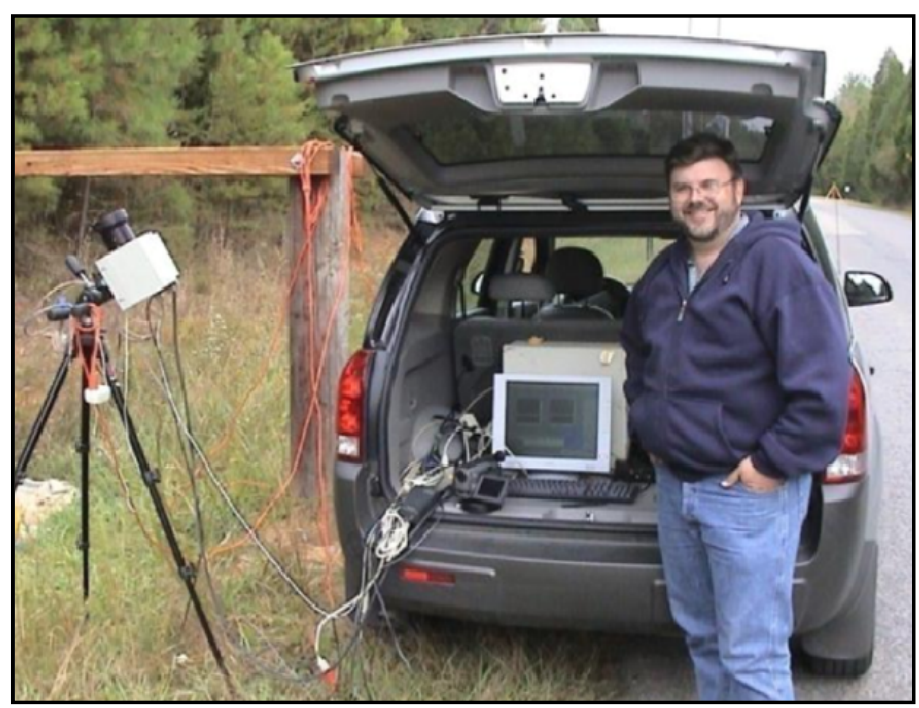

\section{Ralph Dinwiddie}

1957-2020

Ralph Barton Dinwiddie Jr. passed away, age 62, on 9 April 2020, following a multi-year battle with throat cancer. Ralph was one of the leaders of the Thermosense conference for many years. He chaired or co-chaired the Thermosense conference four times (2000, 2001, 2009, and 2010), chaired technical sessions every year, served on the steering committee for decades, was an active participant in conference planning, and developed sessions for evolving applications.

Ralph was born 6 July 1957 and was raised in Atco, south New Jersey (United States). He graduated from Stockton State University, New Jersey (United States) with a BS in Applied Physics, and went on to earn an MS and Ph.D in Physics at the University of Delaware (United States).

He moved to East Tennessee to work at Oak Ridge National Laboratory (United States), where he worked for over 30 years, ultimately as a Senior Research Scientist. He was the leader of the Thermography and Thermophysical Properties User Center at the High Temperature Materials Laboratory (United States).

He loved every minute of his job, often saying he felt "like a little boy in a toy store".

Ralph was a world leader in infrared thermography, which provided him endless research opportunities. Among his favorite assignments were investigating the Civil War Hunley submarine, examining paintings and their alleged relation to Jack the Ripper, and developing a nanocomposite separator. For the latter he 
and his colleagues received a prestigious R\&D 100 Award, which recognizes the 100 most technologically significant products.

He was a leading member of the International Thermal Conductivity Conference, having served as president and conference chairman.

He has over 100 technical publications and 2 patents.

Tirelessly curious, Ralph had many hobbies, interests, and projects.

He was an avid stamp collector and was past president of the Knoxville Philatelic Society (United States).

Ralph also loved good food and was an excellent chef.

He never stopped learning and dreamt of returning to college after retirement and traveling with Sharon, his wife of 37 years.

Ralph leaves behind his beloved wife of 37 years, Sharon, his son Joseph, daughter Samantha, and his brother David.

Ralph will be greatly missed by the infrared community and Thermosense conference.

\section{Individual Tributes to Ralph}

I am fortunate to have known Ralph Dinwiddie. I had a lot of respect for him; he was very bright, enthusiastic, and helpful. I could always rely on Ralph. When he chaired a session, or co-chaired the conference with me, I knew he'd have everything well organized and I wouldn't need to check on anything. He initiated several new sessions on emerging applications and recruited many papers for the sessions he chaired.

In addition to sharing an interest in Infrared NDT and other applications, Ralph and I both worked on thermal properties measurements, including thermal conductivity and thermal expansion. We had many discussions on that topic over the years.

I'll miss Ralph, both professionally and personally.

Doug Burleigh

Ralph Dinwiddie was a great man and a real asset to our planet.

Bob Madding

Proc. of SPIE Vol. 11409 1140901-10 
Ralph was a very smart, humble, and low-key person.

He was more concerned for the group than for the personal benefits that he could obtain.

He was a baseball fan. Once in Baltimore after the conference was finished for the day, he and I went to watch the Baltimore Orioles play a night game.

Ralph was passionate about infrared cameras, software, and infrared applications.

He developed the infrared image gallery at Thermosense.

Among the IR applications that he explored were industrial processes and additive manufacturing.

Andres Rozlosnik 
Proc. of SPIE Vol. 11409 1140901-12

Downloaded From: https://www.spiedigitallibrary.org/conference-proceedings-of-spie on 26 Apr 2023 Terms of Use: https://www.spiedigitallibrary.org/terms-of-use 